\section{Murray Burton Levin}

Murray Burton Levin, Professor Emeritus of Political Science at Boston University, died December 8, 1999, of heart problems at the age of 72. A native of Brookline, Massachusetts, Murray was educated at Harvard (B.A., 1948), where he wrote his honors thesis under the direction of Louis Hartz, and at Columbia (Ph.D., 1955), where his principal mentor was Franz Neumann. Upon these influences, and with insights taken from study of the theoretical and methodological writings of Freud, Marx, their forbears, and their followers, Murray developed an original and highly coherent intellectual perspective.

After teaching at Columbia from 1951 to 1953 , and serving a brief stint in the Navy, Murray came to Boston University in 1955. From that time until his retirement in 1990 , he was arguably the single most popular teacher and most recognized individual on campus. By his own estimate- which may have been a rare understatement-Murray taught more than 18,000 students during his $\mathrm{BU}$ career. Most experienced him as a lecturer of rare power and magnetism, who challenged students to think critically and to question conventional wisdom in Introduction to American Politics or American Political Thought. For others, his seminars on Marxism, Post-Marxist Thought, or Class and Consensus in American Politics provided model experiences in critical textual analysis and logical rigor. After retiring from BU, Murray taught at the Harvard University Extension School and at Stonehill College, where he was a visiting scholar in the Joseph Martin Institute for Law and Society from 1995 to 1999. In both places, he rapidly developed enthusiastic followings of students and faculty attracted by his unique blend of intellectual and personal magnetism.

Murray's published works, taken together, comprise a wholly original and rewarding exploration of the inability of American political culture and electoral processes to address the persistence of poverty, hunger, intolerance, and structural inequalities. In The Alienated Voter (1960), Murray identified and explored the previously unrecognized phenomenon whereby "voters feel impotent, believe that all politicians are crooks and assume that the outcome of elections is meaningless." Political strategies and campaign technologies developed by candidates to appeal to alienated voters are detailed and deconstructed in The Compleat Politician (1962) and Kennedy Campaigning (1966). Political Hysteria in America (1971), Edward M. Kennedy: The Myth of Leadership (1980), and Talk Radio and the American Dream (1986) all in different ways deal with mechanisms developed by elites to shape and channel mass discontent in directions that reinforce or protect the status quo. When he died, Murray was working on a critical analysis of the role media consultants play in modern elections to be titled Political Consultants in the Age of Illusion. In an electoral season characterized by the near total absence of real issues, aggrandizement of style over substance, and blatant week-by-week manipulation of candidates' images, the importance of Murray Levin's intellectual legacy has never been more evident.

Murray's last book, Teach Me: Kids Will Learn When Oppression Is the Lesson (1998), grew out of two years' experience as a volunteer teacher at an alternative high school serving Boston's minority community. During those two years, the 70 year-old Jewish intellectual earned the friendship and trust of some of the city's most disadvantaged and disaffected young people. In remarkably vivid and evocative language, Levin portrayed the worldview of these young people, explicated the mechanisms by which America's social institutions, educational system, and communications media tacitly conspire to keep poor children dysfunctional, and describes the pedagogical techniques which helped them achieve beyond any of Murray's expectations.

The qualities that made Murray Levin a great teacher and insightful critic of American democracy also made him a great colleague and friend. He brought an enormous energy and sense of expectation into every room he ever entered. His passion and the depth of his commitment to both the people and the ideas he cared so much about was always evident, as was his unparalleled generosity of spirit and mind. And finally, no one who knew him could fail to remark on Murray's astonishing and ever present sense of humor.

Murray's humor, like his politics, was an expression of a fundamental irreverence. It sometimes appeared that Murray took it as his life's mission to deflate the self-important, to debunk the conventional wisdom, and-to borrow one of his favorite phrases - to delegitimize authority. This irreverence, and his willingness to challenge authority, was more than stylistic or intellectual. He had rare courage, placing friendship and principle before self on numerous occasions. For many years, the university administration froze his salary on account of political disagreements. When Murray and four other faculty members honored the picket line of a staff union that had supported the faculty's own successful unionization effort, they were threatened with termination; the threat evaporated in the face of overwhelming community and national support.

Murray married for the first time in his fifties. He was a devoted husband to Helen (Jacobson) and quickly established close and loving bonds with her three children, Seth, Jessica, and Jacob. When their son Joshua (now 14) was born, it was the happiest event of his life. He was as extraordinary a father as he was a teacher, a colleague, and a friend.

Edward E. Berger, Ph.D.

\section{Frank A. Pinner}

Frank A. Pinner, Professor Emeritus of Political Science at Michigan State University, was born in Koenigsberg, Germany (then East Prussia; now Kaliningrad, Russia), in 1914. He left Germany in 1933, when the Nazis consolidated their power and went first to Paris, where in 1937 he received a bachelor's degree in economics from the Ecole 